\title{
Two thrush species as dispersers of Miconia prasina (Sw.) DC. (Melastomataceae): an experimental approach
}

\author{
Alves, MAS. ${ }^{\mathrm{a} *}$, Ritter, PD. ${ }^{\mathrm{b}}$, Antonini, $R D .^{\mathrm{c}}$ and Almeida, EM. ${ }^{\mathrm{a}, \mathrm{d}}$

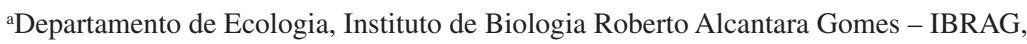 \\ Universidade do Estado do Rio de Janeiro - UERJ, \\ Rua São Francisco Xavier, 524, Maracanã, CEP 20550-011, Rio de Janeiro, RJ, Brazil \\ bPrograma de Pós Graduação em Biologia, Instituto de Biologia Roberto Alcantara Gomes - IBRAG, \\ Universidade do Estado do Rio de Janeiro - UERJ, \\ Av. 28 de setembro, 87, Fds, $4^{\circ}$ Andar, Vila Isabel, CEP 20551-030, Rio de Janeiro, RJ, Brazil \\ 'Programa de Pós Graduação em Biologia Animal, Instituto de Biologia, \\ BR 465, Km 7, Campus Universitário, Seropédica, CEP 23890-000, RJ, Brazil \\ dPrograma de Pós-Graduação em Ecologia, Universidade Federal do Rio de Janeiro - UFRJ, Cidade Universitária - CCS \\ Bloco A s/a 1-08, Ilha do Fundão, CEP 21941-540, Rio de Janeiro, RJ, Brazil \\ *e-mail: masaal@globo.com \\ Received June 30, 2006 - Accepted February 16, 2007 - Distributed May 31, 2008
}

(With 2 figures)

\begin{abstract}
We carried out a seed germination experiment using two thrush species in captivity. We compared the number of germinated seeds and germination time of control seeds (manually removed from fruits) and ingested seeds of Miconia prasina by two bird species, Turdus albicollis and T. amaurochalinus, and also compared retention times of seeds by both thrush species. Control seeds germinated more frequently than those ingested for one species, T. albicollis. The germination time of ingested seeds by T. amaurochalinus was similar to the control seeds but seeds ingested by T. albicollis took longer to germinate than the controls. Both thrush species had a similar seed defecation pattern. The cumulative number of defecated seeds increased by 2 hours after fruit ingestion. At the end of the first 30 minutes both species had already defecated approximately $50 \%$ of the seeds ingested Our results suggest that both species could act as disperser agents of M. prasina.
\end{abstract}

Keywords: Atlantic forest, frugivory, seed germination, Melastomataceae, Turdus.

\section{Duas espécies de Turdus como dispersoras de Miconia prasina (Melastomataceae): uma abordagem experimental}

\begin{abstract}
Resumo
Realizamos um experimento de germinação utilizando duas espécies de Turdus em cativeiro. Comparamos o número de sementes germinadas e o tempo de germinação entre sementes controle (manualmente removidas dos frutos) e ingeridas de Miconia prasina por duas espécies de aves, Turdus albicollis e T. amaurochalinus, e também comparamos o tempo de retenção das sementes pelas duas espécies de Turdus. Sementes controle germinaram com maior frequiência do que as ingeridas por uma das espécies, T. albicollis. O tempo de germinação das sementes ingeridas por T. amaurochalinus foi semelhante ao das sementes controle, mas as sementes ingeridas por T. albicollis demoraram mais para germinar do que as sementes controle. Ambas as espécies de Turdus tiveram um padrão similar de defecação das sementes. O número acumulado de sementes defecadas aumentou por 2 horas após a ingestão dos frutos. Ao final dos primeiros 30 minutos ambas espécies já haviam defecado aproximadamente $50 \%$ das sementes ingeridas Nossos resultados sugerem que as duas espécies de aves podem atuar como agentes dispersores de sementes de M. prasina.
\end{abstract}

Palavras-chave: Mata Atlântica, frugivoria, germinação de sementes, Melastomataceae, Turdus.

\section{Introduction}

Seed dispersal depends on many aspects of the plant-disperser interaction (Herrera, 1995). For example, retention time, manipulation tactic, number of seeds, and place where seeds are deposited are all important for the qualitative and quantitative importance of the seed dispersal agent (Barnea et al., 1992). Classically, pulp removal has been suggested as advantageous since it may enhance seed germination (Ridley, 1930), because the pulp may inhibit germination or be infected by patho- gens (Traveset, 1998). Different bird species may be able to treat pulp and seeds differently (Levey, 1986). Small seeds, such as those of Miconia (Melastomataceae), are more slowly separated from pulp than large seeds. Therefore, small seeds are retained longer in the gut (when compared with regurgitated seeds), which might reduce their viability (Murray et al., 1994) but, in general, seeds defecated by frugivores are viable (see Smith, 1975; Levey, 1986). 
Many studies on the effects of seed germination after ingestion by birds showed that germination is variable (Smith, 1975; Sorensen, 1981; Izhaki and Safriel, 1990; Barnea et al., 1991; Ellison et al., 1993; Castiglioni et al., 1995; Traveset, 1998; Figueroa and Castro, 2002), specially those of germination of seeds collected from feces and seeds extracted manually from pulp (Ellison et al., 1993; Samuel and Levey, 2005). Experimental studies are important as the results can give us clues to comprehend the process of seed dispersal in nature.

Trees and shrubs of the genus Miconia (Melastomataceae) are conspicuous elements in the secondary vegetation (Talora and Morellato, 2000; Manhães, 2003; Oliveira, 2002) producing small berries containing a large number of small seeds (Snow, 1965). Melastome fruits are consistently mentioned as being among the most important resource for many frugivorous birds in the tropics (Snow, 1965; Snow, 1981; Loiselle and Blake, 1990; Stiles and Rosselli, 1993; Galetti and Stotz, 1996), providing fruits at times when fruits in general are scarce (Levey, 1990).

Thrush species are frequent consumers of fruits produced by Melastomataceae, including Miconia species (Levey, 1990; Stiles and Rosselli, 1993; Galetti and Stotz, 1996; Pereira and Mantovani, 2001; Marcondes-Machado, 2002). However, in Brazil, few germination experiments report Atlantic forest plant species, their frugivores, and the efficiency of those consumers.

The goals of the present study were: 1 ) to test whether two thrush species impede or improve germination of Miconia prasina (Sw.) DC. after ingestion; 2) to test whether the time until germination is reduced or not in defecated seeds compared to the control, and 3) to compare seed retention time after ingestion by both thrush species, to determine whether the two thrush species are equal as dispersers agents of M. prasina.

\section{Material and Methods}

\subsection{Study site}

The study was carried out at a secondary Atlantic forest area near Vila Dois Rios ( $23^{\circ} 11^{\prime} \mathrm{S}$ and $44^{\circ} 12^{\prime} \mathrm{W}$ ), in Ilha Grande (Figure 1), the largest island (approximately 19,000 ha) on the coast of Rio de Janeiro State, southeastern Brazil. Ilha Grande is covered by Atlantic forest in different successional stages because of prior agricultural activities, with some areas of undisturbed forest being present in the centre of the island. The climate is warm and humid, with mean annual temperature of $23{ }^{\circ} \mathrm{C}$ and total annual rainfall of $2200 \mathrm{~mm}$ (data obtained from the Central Nuclear Almirante Álvaro Alberto meteorological center - CNAAA).

\subsection{Study plant species}

Miconia prasina is a typical early successional species with small seeds (mean \pm sd) $(81.4 \pm 5.7$ seeds per fruit; $\mathrm{n}=11)$ inside purple berries $(4.5 \pm 0.3 \mathrm{~mm}$ lenght; $6.1 \pm$ $0.6 \mathrm{~mm}$ width; $0.12 \pm 0.03 \mathrm{~g} ; \mathrm{n}=37$ ). This plant occurs

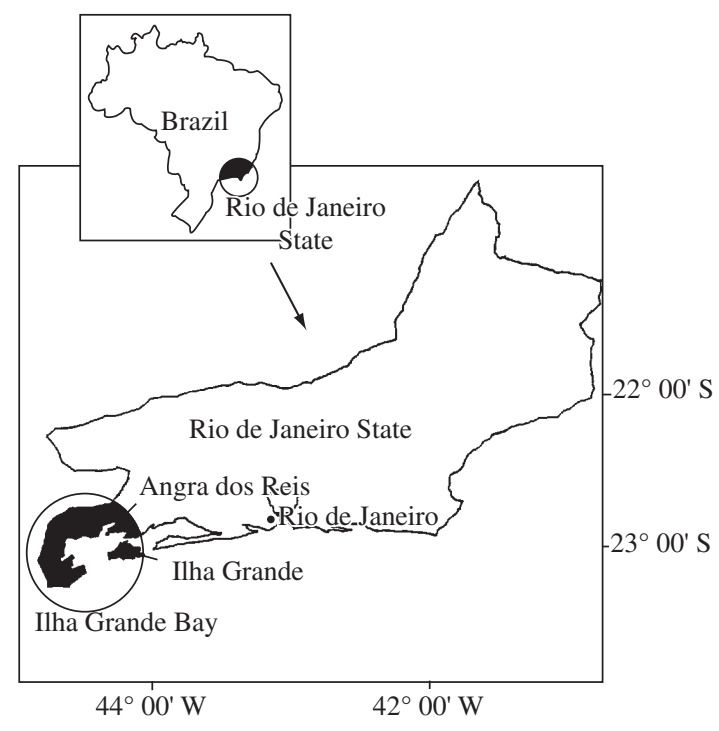

Figure 1. Geographic location of Ilha Grande island at Ilha Grande Bay, in Rio de Janeiro State, Brazil. Source: Alves et al., 1998.

in different areas of Atlantic forest in Brazil (Talora and Morellato, 2000; Oliveira, 2002; Antonini and Freitas, 2004) mostly in forest edges and in regenerating areas, and their fruits are an important food resource for species of different bird families (Correia, 1997).

\subsection{Study bird species}

The White-necked Thrush, Turdus albicollis Vieillot 1818, inhabits mainly the forest (Sick, 1997), and it has been seen feeding on fruits of Miconia species at the forest edge (R.D. Antonini, unpublished data) and the Creamy-bellied Thrush, T. amaurochalinus Cabanis 1851 is found in open habitats, such as the border of the forests (Sick, 1997), secondary forests (M.A.S. Alves unpublished data) and restingas (Alves et al., 2004). It also feeds on fruits and arthropods (Gomes, 2006).

\subsection{Germination studies}

Fieldwork was carried out in the months of August and September 1999 and 2001, during the fruiting period of M. prasina. For the germination experiment, three individuals of T. albicollis and four of T. amaurochalinus were captured and kept in individual cages $(53 \times 46 \times 30 \mathrm{~cm})$ and tested with $M$. prasina fruits, all taken from the study population site. Only completely ripe and not damaged fruits were collected on the day of the experiment. Birds were maintained for three days for acclimatization and fed with a standard diet (following Denslow et al., 1987) and water ad libidum. On the morning of the fourth day, 10 ripe berries of $M$. prasina (from seven individuals) were offered to each bird and feces were collected every 10 minutes (after the first fruit was eaten) within the first 30 minutes, and after that every 30 minutes during 4 hours and 30 minutes, totaling 12 samples collected for 
every bird. After the trial, birds were released in the area where they had been captured.

Seeds found in feces were washed with distilled water and sown in petri dishes with filter paper (both autoclaved to prevent contamination). Control seeds were taken manually from intact fruits and washed with distilled water. In each experimental time interval, ten defecated seeds and ten control were placed in different petri dishes for germination comparisons. If fewer than 10 seeds were defecated then the total number of seeds (from two to nine) was used along with the same number of control seeds.

All seeds were wetted every two or three days with distilled water and the Petri dishes were kept in the laboratory under continuous white light and the same conditions of temperature and humidity with no artificial control of them. The seeds were checked weekly (every two or three days) for 50 days. The emergence of the radicle indicated germination. The day of the first seed germinated in each Petri dish was used to estimate the germination of ingested and control seeds.

To compare germination efficiency among treatments (control and experiment) Chi-square test was used. The germination time among ingested and control seeds were compared using a Mann-Whitney test. The difference between the speed of the germination curves between seeds ingested and control was tested by Kolmogorov-Smirnov test. Tests followed Zar (1999), using the Statistical Software Systat 8.0.

\section{Results}

Overall, the ingested seeds germinated less than the control seeds (Table 1), even though there was significant difference only for $T$. albicollis. The number of germinated seeds did not differ significantly after ingested by both thrushes $\left(\chi^{2}=1.36, \mathrm{p}>0.05\right)$.

Seeds ingested by $T$. albicollis took significantly more time to germinate than the control seeds (Table 2). The difference between the speed of the germination curves between seeds ingested and control for T. albicollis was marginally significant (Kolmogorov-Smirnov test, $\mathrm{KS}=0.41, \mathrm{p}=0.071$ ) while no significant difference was found for T. amaurochalinus (Kolmogorov-Smirnov test, $\mathrm{KS}=0.23, \mathrm{p}=0.476$ ).

Table 1. Absolute number and percentage of seed germination of control and ingested seeds of Miconia prasina by Turdus albicollis (White-necked Thrush) and T. amaurochalinus (Creamy-bellied Thrush).

\begin{tabular}{lccc}
\hline & $\begin{array}{c}\text { Germinated } \\
\text { seeds }\end{array}$ & $\chi^{2}$ & p \\
\hline T. albicollis $\mathrm{n}=190$ & $115(60.5 \%)$ & & \\
Control seeds $\mathrm{n}=190$ & $137(72.1 \%)$ & 5.70 & $<0.05$ \\
T. amaurochalinus & $159(66.0 \%)$ & & \\
$\mathrm{n}=241$ & & & \\
Control seeds $\mathrm{n}=241$ & $168(69,7 \%)$ & 0.77 & $>0.05$ \\
\hline
\end{tabular}

Both Turdus species had a similar pattern of seeds defecation (Figure 2) with the exponential phase between the first hour and the stationary phase reaching after 3 hours (T. albicollis) or 4 hours (T. amaurochalinus). The greatest number of seeds recorded in a single interval was at 30 minutes after ingestion for both species. Through this time interval T. albicollis had defecated $50 \%$ $(\mathrm{n}=823)$ of the ingested seeds and T. amaurochalinus $54 \%(n=1123)$ (Figure 2). The retention time of the seeds in the digestive tract did not differ between the studied species $(\mathrm{U}=1191.0 ; \mathrm{p}=0.805)$.

\section{Discussion}

The closely related thrush species studied in the present work differed in terms of seed germination of M. prasina, as the seeds defecated by $T$. amaurochalinus germinated faster than those ingested by $T$. albicollis.

Passage through digestive tracts of birds increases seed germination (Izhaki and Safriel, 1990). Ingestion may have consistent influence on seed germination (Lieberman and Lieberman, 1986, Barnea et al., 1991; Mallet-Rodrigues, 2001), since it can cause changes at external structure of the seeds (thermic, chemical and mechanical action) and consequently dormancy removal (Agami and Waisel, 1988; Izhaki and Safriel, 1990; Barnea et al., 1991), or on seed viability (Figueroa and Castro, 2002). Birds had an effect on the rate of germination (55\% of the studies), accelerating the germination of ingested seeds more commonly than delaying (Traveset, 1998). In the present study seed ingestion for both thrushes decreased the number, and for T. albicollis delayed the time of seeds germination. Seed germination should be favored after pulp removal, if the pulp has germination inhibitors or is infected by fungi or other pathogens (Traveset, 1998) more easily than seeds separated from the pulp (Traveset, 1998). But only few studies used intact fruits (with seeds left in the fruits) as control (Traveset, 1998; Samuel and Levey, 2005). The results

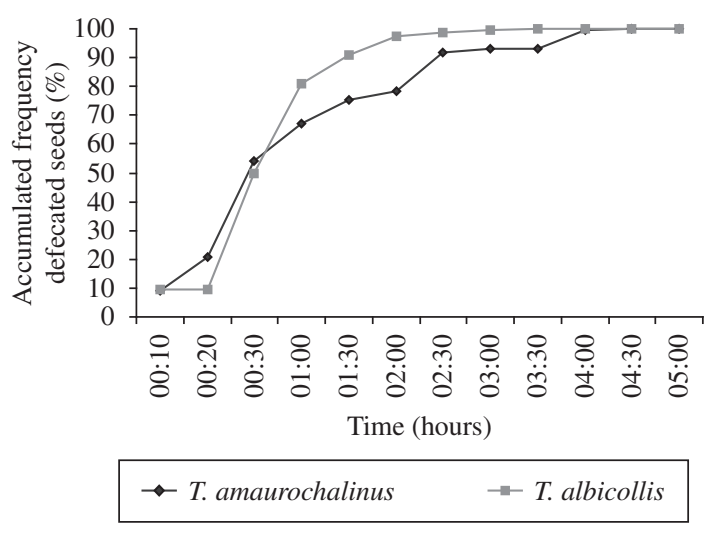

Figure 2. Accumulated frequency of seeds recorded in feces of Turdus amaurochalinus (Creamy-bellied Thrush) ( $\mathrm{n}=1123$ seeds), and T. albicollis (White-necked Thrush) $(\mathrm{n}=823$ seeds) after ingestion of Miconia prasina fruits. 
Table 2. Germination time (mean $\pm \mathrm{sd}$ ) of Miconia prasina controls and ingested seeds by Turdus albicollis (White-necked Thrush) and T. amaurochalinus (Creamy-bellied Thrush).

\begin{tabular}{lcccc}
\hline & \multicolumn{1}{c}{ Ingested seeds } & Control seeds & Mann-Whitney test & p \\
\hline T. albicollis & $25.6 \pm 10.3(\mathrm{n}=17)$ & $19.8 \pm 4.7(\mathrm{n}=21)$ & 108.5 & 0.038 \\
T. amaurochalinus & $17.0 \pm 4.7(\mathrm{n}=24)$ & $16.6 \pm 6.1(\mathrm{n}=26)$ & 274.5 & 0.463 \\
\hline
\end{tabular}

of the present study suggest that the passage through the digestive tract of $T$. amaurochalinus seems not to have a negative effect on seeds germination as observed for the seeds ingested by T. albicollis which germinated significantly less than the controls. However, both thrush species may favor Miconia seeds germination after pulp removal.

Longer retention times of seeds in digestive systems might cause a stronger effect of seed coat abrasion and therefore better germination (Barnea et al., 1991). However it does not explain the difference found in the present study for ingested and control seeds for T. albicollis in terms of seed germination, since there was no evidence of different times of seed retention between the thrush species.

Turdus albicollis was the most captured bird in the understory of a forest less disturbed by man (Alves, 2001), feeds on fruits and arthropods, and preliminary data suggest it is an opportunistic species in terms of its diet (R.D. Antonini and V.C. Tomaz unpublished data). This species can potentially transport seeds from the interior to the edge of the forests and vice-versa. On the other hand, T. amaurochalinus is found in open habitats, feeding also on fruits and arthropods (Gomes 2006). This species is migrant and its role on seeds dispersion deserves further investigation, as migrant bird species have been reported as important seed dispersers of different species in arid Mediterranean habitats (Barnea et al., 1992) and tropical ones (Mallet-Rodrigues, 2001). The process of forest regeneration does not depend exclusively on specialist frugivorous, but also on a large number of generalist species of secondary forests, with diet generally based on fruits and insects, including species of Muscicapidae (see Jordano et al., 2006) family of the Turdus studied.

Individuals of Turdus albicollis and T.amaurochalinus are gulpers (eating the whole fruits and ingesting all seeds) (Stiles and Rosseli, 1993; pers. obs.), and are expected to transport, defecate away from the parental plant (Stiles and Rosselli, 1993). As the Atlantic forest is nowadays distributed in many small fragments, the opportunistic feeding behavior of both bird species may increase the probability of $M$. prasina seeds to be dispersed between forest patches and colonization of new areas. In the same study area a previous study on T. albicollis using capture-marking-recapture in two sampled areas $1 \mathrm{~km}$ far from each other, crossed by a river, three individuals captured in one location were recaptured in the other one (Ritter 2000). This indicates that T. albicollis move between habitats.
Although we do not have much information on the foraging tactics of both Turdus species, our results suggest that both bird species act as dispersers agents of $M$. prasina. Further studies can elucidate the role of time delay on seeds germination by dispersers, such as T. albicollis, compared to the control.

Acknowledgements - This study is part of the results of the Ecology Conservation and Management of South-Eastern Brazilian Ecosystem Program and of the South-Eastern Brazilian Vertebrate Ecology Laboratory, both of Departamento de Ecologia, Instituto de Biologia Roberto Alcantara Gomes, Universidade do Estado do Rio de Janeiro (UERJ). We thank the Coordination of CEADS/UERJ for local support. We also thank Sub-Reitoria of Graduation (SR-2/UERJ) for institutional support and for supplying many facilities during the development of this study. We are grateful to J.F.A. Baumgratz from the Botanical Garden of Rio de Janeiro who identified the Melastome species and all those who helped in field and laboratory work. We also thank Davor Vrcibradic for reviewing the manuscript. This study was partially supported by Conselho Nacional de Desenvolvimento Científico e Tecnológico (CNPq) with a research grant to M.A.S. Alves (no. 302718/2003-6), a Master scholarship to E.M. Almeida ( $\mathrm{n}^{\circ}$ 131560/1998-0) and a under graduation scholarship to R.D. Antonini. P.D. Ritter, received a scholarship from the Brazilian Ministry of Education (CAPES).

\section{References}

AGAMI, M. and WAISEL, Y., 1988. The role of fish in distribution and germination of seeds of the submerged macroohytes Najas marina L. and Ruppia maritima L. Oecologia, vol. 76, p. 83-88

ALVES, MAS., ROCHA, CFD.,Van-SLUYS, M. and BERGALLO, HG., 1998. Guildas de beija-flores polinizadores de quatro espécies de Bromeliaceae de Mata Atlântica da Ilha Grande, RJ, Brasil: composição e taxas de visitação. In ALVES, MAS., SILVA, JMC., Van-SLUYS, M., BERGALLO, HG. and ROCHA, CFD. (orgs). A Ornitologia no Brasil: pesquisa atual e perspectivas. Rio de Janeiro: EdUERJ.

ALVES, MAS., 2001. Estudos de Ecologia de Aves na Ilha Grande, RJ. In ALBUQUERQUE, JLB., CANDIDO-Jr, JF. and STRAUBE, FC. (eds). Ornitologia e Conservação: da Ciência às Estratégias. Florianópolis: Unisul.

ALVES, MAS., STORNI, A., ALMEIDA, EM., GOMES, VSM., OLIVEIRA, CHP., MARQUES, R. and VECCHI, MB., 2004. Estudos da avifauna no Parque Nacional de Jurubatiba. In: ROCHA, CFD., ESTEVES, FA. and SCARANO, FR. (eds). Ecologia, História Natural e Conservação do Parque Nacional da Restinga de Jurubatiba, Programa de Pesquisas Ecológicas de Longa Duração - PELD/CNPq/Site 5. São Carlos, SP: Ed. RiMa.

ANTONINI, RD. and NUNES-FREITAS, AF., 2004. Estrutura populacional e distribuição espacial de Miconia prasina D.C. (Melastomataceae) em duas áreas de Floresta Atlântica na Ilha 
Grande, RJ, Sudeste do Brasil. Acta Bot. Bras., vol. 18, no. 3, p. 671-676.

BARNEA, A., YOM-TOV, Y. and FRIEDMAN, J., 1991. Does ingestion by birds affect seed germination? Functional Ecology, vol. 5 , p. 394-402.

BARNEA, A., YOM-TOV, Y. and FRIEDMAN, J., 1992. Effect of frugivorous birds on seed dispersal and germination of multiseeded fruits. Acta Ecologica, vol. 13, no. 2, p. 209-219.

CASTIGLIONI, GDA., CUNHA, LST. and GONZAGA, LP., 1995. Ramphocelus bresilius como dispersor das sementes de plantas da restinga de Barra de Maricá, estado do Rio de Janeiro (Passeriformes: Emberezidae). Ararajuba, vol. 3, p. 94-99.

CORREIA, JMS., 1997. Utilização de espécies frutíferas da Mata Atlântica na alimentação da avifauna da Reserva Biológica de Poço das Antas, RJ. (Dissertação de Mestrado) Universidade de Brasília.

DENSLOW, JS., LEVEY, DJ. and MOERMOND, TC., 1987. A synthetic diet for fruit-eating birds. Wilson Bulletin, vol. 99, p. 131-135.

ELLISON, MA., DENSLOW, JS., LOISELLE, BA. and BRENÉS, MD., 1993. Seed and seedling ecology of neotropical Melastomataceae. Ecology, vol. 74, no. 6, p. 1733-1749.

FIGUEROA, JA. and CASTRO, SA., 2002. Effects of bird ingestion on seed germination of four woody species of temperate rainforest of Chiloé island, Chile. Plant Ecology, vol. 160 , no. 1 , p. 17-23.

GALLETI, M. and STOTZ, D., 1996. Miconia hypoleuca (Melastomataceae) como espécie chave para aves frugívoras no Sudeste do Brasil. Revta. Brasil. Biol., vol. 56, no. 2, p. 435-439.

GOMES, VSM., 2006. Variação espaço-temporal de aves na Restinga de Jurubatiba, RJ. Programa de Pós-Graduação em Ecologia, (Tese de Doutorado) - Universidade Federal do Rio de Janeiro.

HERRERA, CM., 1995. Plant-vertebrate seed dispersal systems in the Mediterranean: ecological, evolutionary, and historical determinants. Annu. Rev. Ecol. Syst., vol. 26, p. 705-27.

IZHAKI, I. and SAFRIEL, UN., 1990. The effect of some scrubland Mediterranean frugivores upon germination patterns. J. Ecology, vol. 78, no. 1, p. 56-65.

JORDANO, P., GALLETI, M., PIZO, MA. and SILVA, WR., 2006. Ligando frugivoria e dispersão de sementes à biologia da conservação. In ROCHA, CFD., BERGALLO, HG., Van-SLUYS, M., and ALVES, MAS. (orgs). Biologia da conservação: essências. São Carlos, SP: Ed. RiMa.

LEVEY, DJ., 1986. Methods of seed processing by birds and seed deposition patterns. In ESTRADA, A., and TH. FLEMING (eds). Frugivory and seed dispersal. Dordrecht, The Netherlands: Dr. W. Junk Publishers.

LEVEY, DJ., 1990. Habitat-dependent fruiting behaviour of an understory tree Miconia centrodesma, and tropical treefall gaps as keystone habitats for frugivores in Costa Rica. J. Trop. Ecology, vol. 6, p. 409-420.

LIEBERMAN, M. and LIEBERMAN, D., 1986. An experimental study of seed ingestion and germination in a plant-animal assemblage in Ghana. J. Trop. Ecology, vol. 2, p. 113-126.

LOISELLE, B. and BLAKE, J., 1990. Diets of understory fruit eating birds in Costa Rica: seasonality and resource abundance. Studies in Avian Biology, vol. 13, no.13, p. 91-103.
MALLET-RODRIGUES, F., 2001. Potencial de germinação de sementes de Ficus microcarpa tendo o sabiá-laranjeira, Turdus rufiventris, como dispersor. Tangara: Rev. Sul Americana Ornitol., vol. 1, p. 30-33.

MANHÃES, MA., 2003. Dieta de traupíneos (Passeriformes, Emberezidae) no Parque Estadual do Ibitipoca, Minas Gerais, Brasil. Iheringia, Sér. Zool., vol. 93, no. 1, p. 59-73.

MARCONDES-MACHADO, LO., 2002. Comportamento alimentar de aves em Miconia rubiginosa (Melastomataceae) em fragmento de cerrado, São Paulo. Iheringia, Sér. Zool., vol. 92 , no. 3 , p. $97-100$

MURRAY, KG., RUSSEL, S., PICONE, CM., WINNETTMURRAY, K., SHERWOOD, W. and KUHLMANN, ML., 1994. Fruit laxatives and seed passage rates in frugivores: consequences for plant reproductive success. Ecology, vol. 75, no. 4 , p. $989-994$

OLIVEIRA, RR., 2002. Ação antrópica e resultantes sobre a estrutura e composição da Mata Atlântica na Ilha Grande, RJ. Rodriguésia, vol. 53, no. 82, p. 33-58.

PEREIRA, TS. and MANTOVANI, W., 2001. Maturação e dispersão de Miconia cinnamomifolia (DC.) Naud. na Reserva Biológica de Poço das Antas, município de Silva Jardim, RJ, Brasil. Acta Bot. Bras., vol. 15, no. 3, p. 335-348.

RIDLEY, HN., 1930. The dispersal of plants throughout the world. L. Reeve, Ashford, Kent.

RITTER, PD., 2000. Aspectos da dinâmica populacional de Turdus albicollis (Aves, Muscicapidae) em duas áreas de Mata Atlântica na Ilha Grande, RJ. Programa de Pós-Graduação em Biologia, (Dissertação de Mestrado) - Universidade do Estado do Rio de Janeiro.

SAMUEL, IA. and LEVEY, DJ., 2005. Effects of gut passage on seed germination: do experiments answer the questions they ask? Func. Ecology, vol. 19, p. 365-368.

SICK, H., 1997, Ornitologia Brasileira. Rio de Janeiro: Editora Nova Fronteira. 912 p.

SMITH AJ., 1975. Invasion and ecesis of bird disseminated woody plants in a temperate forest sere. Ecology, vol. 56, no. 1, p. 19-34.

SNOW, DW., 1965. A possible selective factor in the evolution of fruiting seasons in tropical forests. Oikos, vol. 15, p. 274-281.

SNOW, DW., 1981. Tropical frugivorous birds and their food plants: a world survey. Biotropica, vol. 13, p. 1-14.

SORENSEN, AE., 1981. Interactions between birds and fruits in a temperate woodland. Oecologia, vol. 50, p. 442-450.

STILES, FG. and ROSSELLI, L., 1993. Consumption of fruits of the Melastomataceae by birds: how diffuse is coevolution? In: FLEMING, TH. and ESTRADA, A. (eds). Frugivory and seed dispersal: Ecological and Evolutionary Aspects. Vegetatio 107/108. Belgium: Kluwer Academic Publishers.

TALORA, DC. and MORELLATO, PC., 2000. Fenologia de espécies arbóreas em floresta de planície litorânea do sudeste do Brasil. Rev. Brasil. Bot., vol. 23, no. 1, p. 13-26.

TRAVESET, A., 1998. Effect of seed passage through vertebrate frugivores's guts on germination: a review. Persp. Plant Ecol., Evol. Syst., vol. 12, no. 2, p. 151-190.

ZAR, JH., 1999. Biostatistical analysis. New Jersey: PrenticeHall. 